\title{
Technological innovations: prospects, development trends
}

\section{application,}

\author{
Maxim Pasholikov ${ }^{1}$, and Georgy Dudakov ${ }^{1 *}$ \\ ${ }^{1}$ Peter the Great St. Petersburg Polytechnic University, Polytechnicheskaya St., 29, St. Petersburg, \\ 195251, Russia
}

\begin{abstract}
Innovations play a decisive role in the country's economy, as they allow making scientific discoveries, improving production, and creating a fundamentally new product. The main goal of the research is to study technological innovations for determining prospects and development trends. Evaluation, comparison, analyzation and systematization methods for data were used throughout the research. Road construction was chosen as the object of the study. Themonitoring result of the innovation development strategy is the definition of boundaries of financing the fundamental and applied science sectors.Support for the commercialization of developments and an assessment of the country's existing innovative potential are also identified. The obtained results allow determining the main application areas of technological innovations.
\end{abstract}

\section{Introduction}

Cybernation and digitization of production processes had a great impact on the development of the national economy of Russia. Robotization of technological processes and the use of intelligent manufacturing technologies create the conditions for processing large amounts of data and making high-quality management decisions. The developing of new industries and materials, the use of artificial intelligence contribute to the implementation of scientific and technological initiatives. These economic transformations determine the main trends and directions of innovative development of Russia. The innovative thrust of the economy determines new development priorities contributing to the systematization of efforts. These efforts areaimed at finding promising areas of programtargeted management of scientific and technological development of production. The issues of innovative development of industrial and service sectors were thoroughly considered in the studies of scientists of the Peter the Great St. Petersburg Polytechnic University [1-5].

\section{Analysis of the main costs of innovation and innovative activities in the Russian Federation}

Innovative development is largely determined by technological innovations implemented in the country's economy, in the roduction sector, agriculture, trade and other industries. The

*Corresponding author: zhoraa1999@,mail.ru 
level and quality of innovative transformations depend on resource support [7-12].

In 2017, technological innovations were implemented at 2321 industrial production organizations, which is $9.6 \%$ of their total number. Between 2013 and 2017 the level of innovation activity did not undergo significant changes and decreased by $0.1 \%$ compared to 2013, which is shown in table 1 . This fact indicates a low development rate of innovation activity.

Costs of technological innovation in industrial production increased by 101268 million rubles at current prices between 2013 and 2017 and amounted to 848046 million rubles. Costs at constant prices in relation to the starting year of 1995 (conditionally taken as the starting point) showed positive dynamics in relation to the previous year and amounted to 26906 million rubles. The costs of technological innovation as a percentage of the total volume of goods shipped, work and services performed in industrial production reflect the negative development dynamics from 2013 to 2017 and make up 1.7\% in 2017.

Table 1. The cost of technological innovation in Russia [13]

\begin{tabular}{|c|c|c|c|c|c|}
\hline & 2013 & 2014 & 2015 & 2016 & 2017 \\
\hline \multicolumn{6}{|c|}{ Industrial production } \\
\hline $\begin{array}{c}\text { Weight of organizations } \\
\text { implementing technological } \\
\text { innovations, in the total number of } \\
\text { organizations }(\%)\end{array}$ & 9.7 & 9.7 & 9.5 & 9.5 & 9.6 \\
\hline $\begin{array}{l}\text { Costs of technological innovation, in } \\
\text { current prices, million rubles }\end{array}$ & 746778 & 762774 & 735758 & 777519 & 848046 \\
\hline In constant prices in 1995 & 29951 & 28458 & 25417 & 25952 & 26906 \\
\hline $\begin{array}{l}\text { as a percentage of the total volume } \\
\text { of goods shipped, works and } \\
\text { services performed }\end{array}$ & 2.2 & 2.1 & 1.8 & 1.8 & 1.7 \\
\hline $\begin{array}{l}\text { The volume of innovative goods, } \\
\text { works, services, in current prices, } \\
\text { million rubles }\end{array}$ & 3072531 & 3037407 & 3258255 & 3723693 & 3403055 \\
\hline In constant prices in 1995 & 123231 & 113323 & 112558 & 124287 & 107970 \\
\hline $\begin{array}{l}\text { as a percentage of the total volume } \\
\text { of goods shipped, works and } \\
\text { services performed }\end{array}$ & 8.9 & 8.2 & 7.9 & 8.4 & 6.7 \\
\hline \multicolumn{6}{|l|}{$\begin{array}{l}\text { Activities in the field of } \\
\text { telecommunications and information } \\
\text { technology }\end{array}$} \\
\hline $\begin{array}{c}\text { Weight of organizations } \\
\text { implementing technological } \\
\text { innovations, in the total number of } \\
\text { organizations (\%) }\end{array}$ & 10.3 & 9.5 & 9.4 & 7.7 & 8 \\
\hline $\begin{array}{l}\text { Costs of technological innovation, in } \\
\text { current prices, million rubles }\end{array}$ & 66133 & 47066 & 66723 & 52734 & 54626 \\
\hline In constant prices in 1995 & 2652 & 1756 & 2305 & 1760 & 1733 \\
\hline $\begin{array}{l}\text { as a percentage of the total volume } \\
\text { of goods shipped, works and } \\
\text { services performed }\end{array}$ & 3.6 & 2.4 & 3.3 & 2.3 & 2.3 \\
\hline $\begin{array}{l}\text { The volume of innovative goods, } \\
\text { works, services, in current prices, } \\
\text { million rubles }\end{array}$ & 71094 & 62929 & 86049 & 80956 & 111255 \\
\hline In constant prices in 1995 & 2851 & 2348 & 2973 & 2702 & 3530 \\
\hline $\begin{array}{l}\text { as a percentage of the total volume } \\
\text { of goods shipped, works and } \\
\text { services performed }\end{array}$ & 3.9 & 3.3 & 4.3 & 3.5 & 4.8 \\
\hline
\end{tabular}


The volume of innovations in industrial production increased by 330,624 million rubles at current prices in 2017 compared with 2013. The volume of innovations in constant prices of 1995, on the contrary, showed a negative trend and decreased by 15261 million rubles for the reviewed period. The volume of innovations as a percentage of the total volume of goods shipped, works and services performed also decreased in 2018 compared to 2013 and amounted to $6.7 \%$ against $8.9 \%$.

Let us analyze the indicators in table 1 regarding the field of telecommunications and information technology. The level of innovation activity increased by $0.3 \%$ compared to the previous year and amounted to $8 \%$ in 2017 . The costs of technological innovation in current prices showed a negative development dynamics in the period from 2013 to 2017 and in 2017 amounted to 54626 million rubles, which is 11507 million rubles less than in 2013 . However, in 2015 there was a significant increase in these costs compared to the previous year and they amounted to 19657 million rubles. The costs of technological innovation in constant prices also represent a decline over five years, they are reduced by 919 million rubles. These costs acquire positive dynamics only in 2015 and increase by 549 million rubles. The costs of technological innovation as a percentage of the total volume of goods shipped, work and services performed decreased over the period under review by $1.3 \%$ and amounted to $2.3 \%$. This value is the lowest for the entire period indicated in the table.

The volume of innovative goods, works, services, in current prices had global growth and increased by 40,161 million rubles during five years. The volume of innovations in constant prices in 1995 increased by 679 million rubles in 2017 compared with 2013. The volume of innovative goods, works, services as a percentage of the total volume of goods shipped, works and services performed increased by $0.9 \%$ for the period under review, and in 2017 it amounted to $4.8 \%$.

According to the analyzed indicators, it can be concluded that there is an investment increase in innovation in the field of industrial production and the field of telecommunications and information technology. There is an increase in innovation activity in the considered key areas. In general, there is a positive trend in the development of innovations in Russia and a further increase in the innovation level.

\section{Application of innovations and innovative technologies in the Russian Federation}

The construction industry was selected as a basis for analysis, as one of the basic industries that determine the development of the Russian economy as a whole. Road construction plays an important role in our country, given the large spatial scales, the need for production and other interconnections. From the perspective of modern Russian realities, the construction of highways in Russia is gaining importance. The development of a network of roads is an essential aspect of development, as they determine the quality and level of people's lives. The construction of roads is the main area of the construction industry, as the length of roads is an important indicator of the country's economic development. The state is actively investing budget money in this industry, as shown in fig. 1.

In 2014, 473 billion dollars were budgeted for the development of road construction, 500 billion rubles in 2017, 533 billion rubles in 2018, and in 2020 it is planned to budget up to 863 billion rubles. The amount of funds allocated for the construction and development of roads in the Russian Federation from 2014 to 2018 increased by $\$ 60$ billion. This is largely due to the decree signed by the President of the Russian Federation V.V. Putin in 2012.According to this decree, it is planned to actively attract foreign investors to the construction and road industry. 


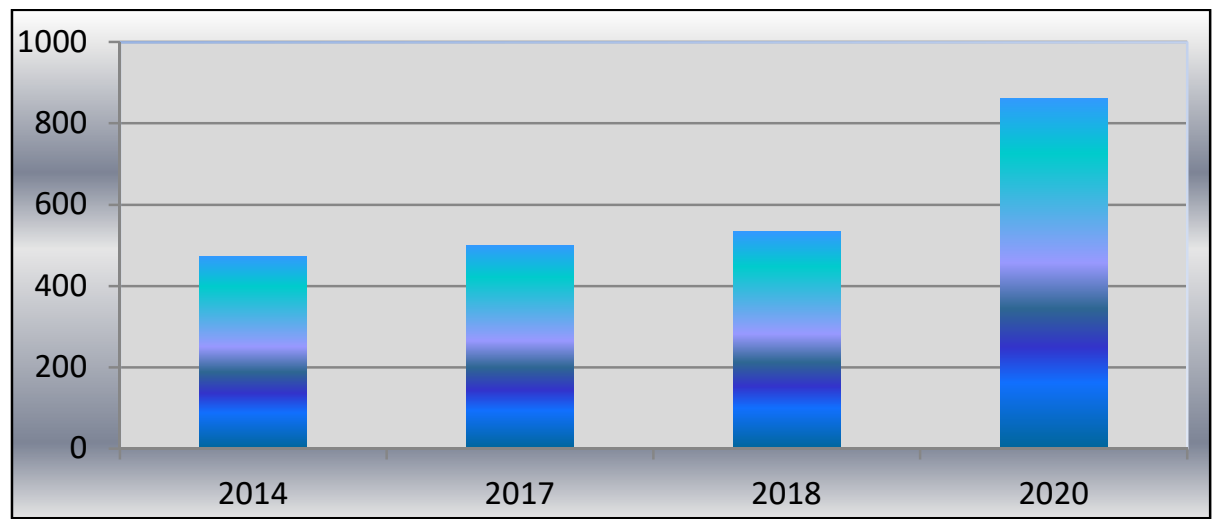

Fig. 1. Funds allocated from the RF budget for the development and construction of roads, billion rubles [14]

The average cost of road construction and reconstruction in different countries is presented in table 2 .

Table 2. The cost of construction and reconstruction of $1 \mathrm{~km}$ of roads in the world [14]

\begin{tabular}{|c|c|c|c|c|c|c|}
\hline & Russia & USA & Canada & Germany & Poland & China \\
\hline $\begin{array}{c}\text { The minimum cost of 1 km of } \\
\text { road, in 2014 prices, million } \\
\text { rubles }\end{array}$ & 11.9 & 32.7 & 36.6 & 5.2 & 12.2 & 10.1 \\
\hline $\begin{array}{c}\text { The average cost of 1 km of } \\
\text { road, in 2014 prices, million } \\
\text { rubles }\end{array}$ & 58.8 & 127.05 & 163.9 & 81.2 & 25.8 & 29.03 \\
\hline $\begin{array}{c}\text { The maximum cost of 1 km of } \\
\text { road, in 2014 prices, million } \\
\text { rubles }\end{array}$ & 243.9 & 389.9 & 330.9 & 348.5 & 42.5 & 82.9 \\
\hline
\end{tabular}

According to the information presented in table 2, it can be concluded that the cost of building roads in Russia is not the highest in the world. The reconstruction and construction cost of $1 \mathrm{~km}$ of the road averages 58.8 million rubles, and the maximum cost of $1 \mathrm{~km}$ of the road is 243.9 million rubles, which is 146 million less than the figure in the USA and 87 million rubles less than this indicator in Canada. Thus, the average indicator of the cost of building $1 \mathrm{~km}$ of roads in Russia is 1.4-2.8 times less than in developed foreign countries.

The Russian HighwaysState Company is engaged in the creation and development using off-budget assets, innovative design techniques and advanced management tools. One of the key solutions to the company's goals is to attract business to the construction of roads. Due to the multivariance of concepts in the construction of complex road infrastructure facilities, technologies and business experience based on innovative technical approaches are highly demanded.

Avtodor Group has developed a strategy for the development of high-speed roads. According to it, it is planned to build more than 12 thousand kmof European quality roads in the Russian Federation by 2030.

A major innovative project in the Russian Federation is the construction of an object of federal significance, which is the express road Moscow - St. Petersburg M-11. Construction of the road began in 2014. The most important goal of constructing this road is to connect the capital of Russia with the largest transport hub in the northwest of the country. The road is planned to be completed by the end of 2019. European level innovative technologies were used for designing and constructing the M-11 express road. The most modern innovative solutions implemented in international practices were used. Weak soils were 
strengthened by reinforcement using high-strength geosynthetics.

Reinforcement is a method of increasing the structure bearing capacity by a material with increased strength properties relative to the main structural material. During construction,soil is cemented through the partial replacement of weak soil with the one havingbetter strength indicators. Moreover, drainage systems made of the cutting edgegeocomposite materials were used during construction, which allowspreventing floods and regulating the water-thermal regime.

Noise screens were used and green spaces were planted in order to comply with environmental safety. Precast reinforced concrete spans made of multifunctional beams were developed, for which modern waterproofing wasused, the newest anti-corrosion protection was used for reinforced concrete constructions.

The construction of innovative roads will allow the Russian Federation to reach a new level of innovative development and greatly improve the quality of people's lives, since people will be able to move between two cities of federal significance by transport. The development of this industry will make it possible to purposefully research the market of innovations and innovative technologies with an analysis of the effectiveness of a particular activity in Russia.

\section{Innovative development strategy of Russian Federation}

A prerequisite for developing a strategy that would determine the path of innovative development for a country is, first of all, the global economic crisis of 2008-2009. That crisis lowered the forecast for GDP growth in Russia in 2013 by $2.5 \%$ from $3.4 \%$ forecasted in April of the same year, and from 3.25\% to 3.8\% in 2014. The production indicators decreased, the probability of a national currency stability decrease was high due to this. Thus, development of an innovative strategy presupposed the creation of fundamentally new products, production technologies, which would strengthen the country's economic stability.

The innovative development strategy of the Russian Federation sets out the functions, goals, objectives and ways of development of state innovation policy. This strategy was approved by the decreeNo. 2227-r of the Russian Federation Government in the period from December 8, 2011 to 2020. The innovation development strategy defines long-term development guidelines for innovative activity entities, the boundaries of financing the fundamental and applied science sectors, and support for the commercialization of development. The strategy plays an important role in the country's economy, being one of the 4 strategic directions of the concept of long-term socio-economic development of the Russian Federation until 2020, which is indicated in Fig. 2.

The innovative development strategy of the Russian Federation is divided into 2 stages, which will be implemented alternately.

The first stage includes the time period from 2011 to 2013. At this stage, the key task is to focus on increasing the susceptibility of entrepreneurship and the economy to innovation through a series of events.

1. The investment increase for promising scientific and technological projects, increasing their investment attractiveness.

2. Attracting new qualified personnel to the high-tech sectors of the country's economy.

3. Stimulating the innovative development of large companies with state participation and monopolies, developing requirements for the innovative concept of their investment programs.

4. The elimination of innovation barriers in the system of state regulation.

5.Support of small business and technology, certain studies provided for high-tech sectors of the economy. 
It is planned to modernize the science and education sectors, the modernization will consist of increasing government investments in innovative research projects, updating management personnel. Another important step is the accession of Russian science to the global scientific community.

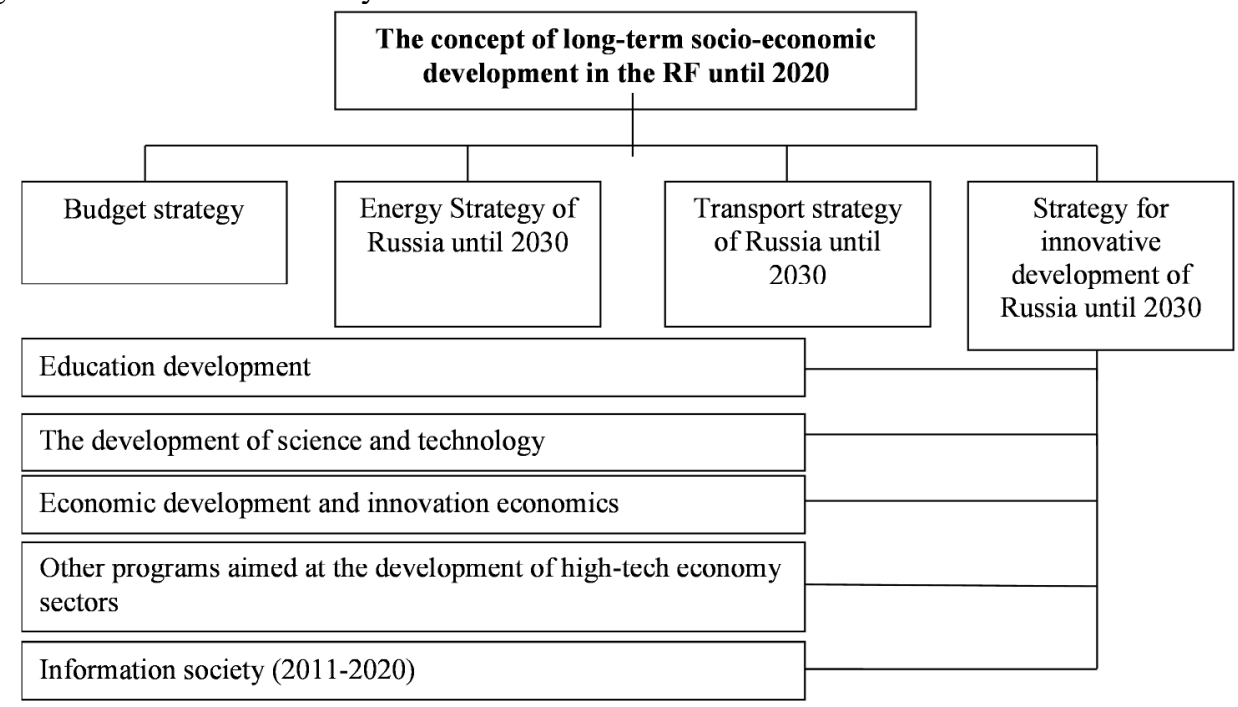

Fig. 2. Innovative development strategy in the concept of long-term economic development of the Russian Federation [15]

The key task in the field of research and development will be the creation of national research centers that are responsible for the innovative development of scientific research and concepts, bringing leading universities of the country to the world level.

The implementation period for the second stage of the innovation development strategy is 2014-2020. During the implementation phase, it is planned to increase the costs of innovation in the Russian budget. Due to the release of financial resources, the inflow of funds to the innovative economy sector, education and science will increase significantly. According to the concepts provided in the first stage of strategy execution, a global improvement of the industry is planned. In key sectors of the economy, enterprises of the Russian Federation will reach the same level as developed countries in terms of the technologies used.

Particular attention is paid to improving and modernizing innovative infrastructure, increasing its effectiveness. The key goal in the implementation of the second stage of the strategy is the final formation of a sole and highly effective innovation system. Such system will be able to satisfy the increasing demand for innovation from the main sectors of the economy, in which innovation allows the creation of new technologies.

At the second stage of the strategy implementation, it is also planned to promote Russian innovative products, developments and technologies to the world market.

The modernization of the scientific base is provided, as well as an increase in the costs of research and development work for civilian purposes.

\section{Conclusion}

Based on the total study, it can be concluded.

1. Digitization and cybernation became the impetus for a new stage in the development of the Russian national economy. Thanks to these two processes, innovations and, as a result, innovative technologies have become widespread. With the help of innovative 
solutions, fundamentally new development technologies and high-quality products with high competitiveness began to appear on the Russian market.

2. In the field of industrial production, telecommunications and information technology, there has been an increase in state investment. The innovation costs in these sectors are increasing, as well as the quality of manufactured products. In the long run, innovation spending will steadily increase every year, which will ensure intensive innovation growth.

3. One of the most important application areas in Russia is the construction of roads. This industry is very important for Russia, since the country is the largest in the world and it is extremely important to provide it with high-quality roads. By the end of 2019, it is planned to complete the construction of the M-11 express road, which will connect Moscow and St. Petersburg, 2 cities of federal significance. The latest technologies were used during the construction of this road, which guarantees the exceptional quality.

4. The main concept of promoting innovation in the Russian Federation is the innovation development strategy. This document defines the development thrust, the main goals and objectives of the innovation sphere in the country. According to the strategy of innovative development, a budget is determined that will be aimed at implementing the newest technologies and production methods.

\section{References}

1. S. Krymov, M. Kolgan et al., IOP Conference Series: Materials Science and Engineering. 012126. (2019) DOI: 10.1088/1757-899X/497/1/012126

2. , S.M. Krymov, I.V. Kapustina, M.V. Kolgan, Proceedings of 2017 IEEE 6th Forum Strategic Partnership of Universities and Enterprises of Hi-Tech Branches (Science. Education. Innovations), SPUE 2017. (2017) DOI: 10.1109/IVForum.2017.8246068

3. S.A. Makarenko, N.Y. Sukhina, S.M. Krymov, S.V. Martynenko, A.A. Adamenko Testing economic systems of capitalist countries by the world economic crisis (Espacios, 2018)

4. I.A. Krasyuk, V.V. Bakharev, Yu.Yu. Medvedeva, SHS Web of Conferences 35. 01052 (2017). DOI: $10.1051 /$ shsconf $/ 20173501052$

5. I.A. Krasyuk, T.V. Kirillova, N.A. Kozlova SHS Web of Conferences 35. 01055 (2017). DOI: $10.1051 /$ shsconf $/ 20173501055$

6. I. Krasyuk, Y. Medvedeva Proceedings of the 33rd International Business Information Management Association Conference, IBIMA 2019: Education Excellence and Innovation Management through Vision (2020).

7. I.A. Krasyuk, Y.Y. Medvedeva Proceedings of the 33rd International Business Information Management Association Conference, IBIMA 2019: Education Excellence and Innovation Management through Vision (2020)

8. I.A. Krasyuk, A.A. Kobeleva et al., Economic interests focusing as a basis of the formation of investment policy (Espacios, 2018)

9. M. Pasholikov, G. Dudakov 33rd IBIMA conference proceedings: 4198-4206

10. S. Krymov, M. Kolgan Proceedings of the 33rd International Business Information Management Association Conference, IBIMA 2019. (2020)

11. V.A. Bondarenko, I.N. Efremenko, V.A. Larionov Marketing Strategy for Hotel and Tourist Complex Companies International Journal of Economics \& Business Administration, VII (Special Issue 1), 388-394 (2019)

12. I. Krasyuk, T. Kirillova et al., IOP Conference Series: Materials Science and Engineering (2019) 
13. T. Nekrasova, V. Leventsov, V. Gluhov. Development of Infocommunications Services in Russia

14. Lecture Notes in Computer Science (including subseries Lecture Notes in Artificial Intelligence and Lecture Notes in Bioinformatics) (2019)

15. V. Gluhov, V. Leventsov et al., Analytical Modelling of Development and Implementation of Telecommunication Technologies

16. Lecture Notes in Computer Science (including subseries Lecture Notes in Artificial Intelligence and Lecture Notes in Bioinformatics) (2018)

17. M. Kolgan, I. Moshkin, E. Nazarova Proceedings of the 33rd International Business Information Management Association Conference (2019)

18. E. Konnikov, O. Konnikova, V. Leventsov, IOP Conference Series: Materials Science and Engineering (2019) 